\title{
"Gettolaşma" Söylemi Bağlamında Sosyo-mekânsal Sürgün Yerleri
}

\author{
Asiye Akgün Gültekin \\ İstanbul Kültür Üniversitesi
}

\begin{abstract}
Öz
Ekonomik, kültürel, sosyal ve politik süreçlerin kent mekânındaki izdüşümü olarak mekânsal dışlama ve kentsel eşitsizliklerin ortaya çıktığı görülmektedir. Bu bağlamda kent peyzajında ortaya çıkan kümelenmeler, 1970 sonrası gelişmiş ülkelerde görülen kentsel hareketler ve aktörler arasındaki ilişkilerin kentsel eşitsizlikleri nasıl tetiklediği sorusu önem kazanmaktadır. Kentsel sosyomekânsal kapanma ya da inziva biçimleri olarak getto ve banliyölerin yapısal ve işlevsel farklllıklarının altının çizildiği; bu tiplerin aynılaştırılmaya çalışılan söylemlerinin arka planında neler olacağı yönündeki tartışmayı içeren çalışmada bir dizi politik ve medya söylemlerine yer verildi. Sömürge sonrası dünya kentlerinde ileri marjinalliğin mekânları olarak genel kabul gören, şiddet ile yaftalanan, heterojen demografinin emek piyasasından dışlandığı, sistemle sorunlu ilişkisinin tanımlandı̆̆ı sürgün yerleri kentsel bir oluşum olarak apaçık karşımızda durmaktadır. Gettolaşan Avrupa söylemlerine, Wacquant'ın değerlendirmeleri paralelinde bakan bu yazının temel endişesi; mekânın sosyal boyutu ve topluluk üzerindeki etkilerini anlamaya yöneliktir. Getto, hipergetto, antigetto kavramları arasındaki farkların neler olduğuna ilişkin tartışma La Haine filmi okuması üzerinden yürütüldü. Bu metnin ortaya çıkışındaki süreçte Fransa'da yaşanan "sarı yelek" protestolarının ekonomik, kültürel ve sosyo-mekânsal bagajlarını deşmek düşüncesi yer alır. Mekânsal dışlamanın etno-ırksal, sınıfsal formlarının arkasındaki ilişkiler ă̆ının haritasının çıkartılması; bu çalışmanın hedefini oluşturmaktadır.
\end{abstract}

Anahtar Kelimeler: Gettolaşma, antigetto, sosyo-mekânsal inziva, söylemsel pratikler, damgalama, paralel topluluk, La Haine

idealkent @ Kent Araştırmaları Dergisi (Journal of Urban Studies)

http://idealkentdergisi.com

Geliş Tarihi Received Date: 20.12.2018 Kabul Tarihi Accepted Date: 25.04.2019 


\title{
Socio-spatial in the Context of the "Ghettozation" Discourse
}

\author{
Asiye Akgün Gültekin \\ Istanbul Technical University
}

\begin{abstract}
Spatial exclusion and urban inequalities are seen as the projections of economic, cultural, social and political processes in the urban space. In this context, the question of how the relations triggered the urban inequalities between clusters that emerged in urban landscapes and urban movements in the developed countries after 1970 and actors gets importance. In this study, a series of political and media reports that include the discussion underlining the structural and functional differences of ghettos and banlieues as urban socio-spatial forms of seclusion is described; what is on the backstage of these types of 'sameness' discourses. The exile locations that are generally accepted as the places of advanced marginality, labeled with violence, excluded from the labor market and the having problematic relations with the system in post-colonial world cities clearly stands in front of us as an urban formation. The main concern of this article which looks at the 'discourses of ghettozation of Europe in line with Wacquant's arguments is to understand the social dimension of the space and its impact on the community. The discussion of the differences between the concepts of ghetto, hyperghetto and antighetto was carried out through the La Haine film reading. This text emerged from the intention of digging the economic, cultural and sociospatial baggage of current yellow vest protests in France. Mapping the network of relations behind the ethno-racial, class forms of spatial exclusion is the target of this study.
\end{abstract}

Keywords: Ghettozation, anti-ghetto, socio-spatial seclusion, discursive practices, stigmatization, parallel society, La Haine 


\section{Giriş}

Kapitalist sistemin 1973 ekonomik krizi beraberinde refah devleti politikalarından vazgeçilmesi ve bunun etkileri ile ilişkili etnik, ırksal ve sınıfsal huzursuzlukların artması kentsel direnişlerin ivmelenen artışını ortaya çıkarttı. Neoliberal politikalar ile mülksüzleştirilen, işsizleştirilen ve yapısal şiddete maruz kalanların çığlığı olarak ortaya çıkan eylemler temelde ekonomik ve mekânsal eşitsizliklerden kaynaklanmaktadır. Marjinalleşen-tirilen kent paryaları, tehlikeli görülen kent mekânları ve kentsel hareketler karşısında; Avrupa toplumlarında ırkçılığın yeniden yükselişine ilişkin endişeler kendini göstermektedir. Diğer taraftan kentsel hareketler karşısında devlet tarafından gösterilen ağırlaşan militer müdahaleler ve ceza-cezalandırma sistemine ilişkin tartışmaların yapılmakta olduğuna şahit olmaktay1z.

Wacquant'in getto/anti-getto/hiper-getto (bu türden mekansal kümelenmeleri Wacquant sürgün yerleri olarak ifade eder ki bu yazıda da bu şekilde kullanılmaktadır) kavramlarının yapısal çözümlemesinin yapmasının üzerinden kabaca yirmi yıl geçmesine rağmen (Urban Outcast yayın tarihini refere ederek), politikacıların getto kavramını kullanmasındaki ısrarın manipülatif olduğunu düşündürür. 20. yüzyıl ortalarındaki komünal gettodan 21. yüzyıl sonuna ait hiper-gettoya tarihi geçişin izini süren Wacquant'a göre ABD kentlerinde görülen komünal gettolarda siyahların tüm sosyal sınıfları kendilerine ayrılmış bir yere tıkılır; sınırlı kesin bir şekilde çizilen bu alanlarda, bu etnik gruba özgü kurumların varlığı eşliğinde sıkışık bir sosyo-mekânsal oluşum içinde ortak bir kader yaşanır iken; hiper-getto, yeni, merkezsiz, belirli bir bölgeyle sınırlı, örgütlenmiş bir yapıdır; burada ırk ve sınıf temelinde birleşik bir ayrım söz konusudur. Bu oluşum; emek piyasasının ve refah devletinin kent merkezinden çekilmesi bağlamında gerçekleşmektedir (Wacquant, 2015, s.13). 1950'lerin komünal gettosunun siyahların marjinalleşmesi ve yaşam alanlarının tekinsiz bir hale gelmesi ile 1990'lar hiper-gettosuna dönüşmesi, yere olan aidiyetleri de olumsuz etkilemiştir. Wacquant (2015, s.14), hiper-gettoların aşırı marjinalleşmesinin temelinde siyasetin, eknomiye göre daha fazla belirleyici olduğunu ifade etmektedir. Avrupa işçi sınıfı banliyölerinde 21. yüzyıldan itibaren başgösteren ileri marjinalliği Amerikan gettolarında yaşananlarla yüzeysel benzerlikleri nedeniyle türdeşleştiren anlayışın karşısında, temelde banliyölerin heterojen yapısı, kent merkezi ile ilişkileri ve bu bölgelere yönelik politik 
yaklaşımları ile gettolardan yapısal ve işlevsel olarak ayıran özellikleri bağlamında Wacquant (2015); işçi sınıfı yerleşmelerinin gettolaşamayacağını olsa olsa anti-getto olabileceğini ileri sürer. Diğer yandan kavramların etimolojik farklılığının görmezden gelinerek Avrupa işçi sınıfı yerleşmelerine (cité) ithafen getto-gettolaşma kavramları ile adlandırmalar, 'paralel yaşamlar'ın lanetlenmesi; Avrupa'nın göbeğinden bu söylemi sistematikleştiren paralel söylemlerin ortaya çıkıyor olması, dünya konjonktürel siyasetine ve ekonomisine bakıldığında yadırganmaması gereken bir durum. İşsizleştirilerek, etnik-sınıf temelli ayrıştırılarak yabancılaştırılan topluluklar; medya ve politika aracılığıyla mekânsal olarak da damgalanmaktadır.

Bu bağlamda çalışmanın çerçevesi; medyada yaratılan panik, sembolik $i k$ tidar ve sembolik şiddet ile ilişkili olarak sosyo-mekânsal inzivanın Avrupa işçi sınıfı yaşam alanları ile gettoların yapısal ve işlevsel farklılıklarını ortaya koymaktadır. Temel olarak bu çalışma, Wacquant'ın 2014 yılında ABD'de Yale Üniversitesi'nde vermiş olduğu kentsel inzivanın tarihçesini anlattı̆̆ 1 "Designing Urban Seclusion" seminerinin deşifrelerine ve ileri marjinalliğin Amerikan ve Avrupa örnekleri üzerinden tartışıldığı "Kent Paryaları" kitabına dayanmaktadır. Üniversitede vermiş olduğum "Mekânsal Ayrışma" seçmeli lisans dersi kapsamında izlettiğim La Haine filmi üzerinden Wacquant okuması yapmaya çalışıyorum. Filmin yönetmeni Kassovitz'in, banliyödeki gündelik hayatı kalıplaşmış steryotiplerden çok farklı olduğunu güçlü bir şekilde vurguladığı ve film müziklerini banliyö müzik kültürünü temsil ettiğini düşündügüm için, bir çok banliyö filmi varken (Jean-Luc Godard'ın 1966 yılı Two or Three Things I Know About Her filmi, Marco Ferreri'nin 1976 yılı The Last Woman filmi, Abdellatif Kechiche'nin 2003 yılı L' esquive filmi gibi) La Haine'i tercih ettiğimi düşünüyorum. Bu yazıyı yazmaya başladığımda "sarı yelek" eylemlerinin ortaya çıkışı ve ardından medyada gündeme gelmesi, yazının araştırma yöntemini biraz genişletmeme sebep oldu. Başlangiçta sadece La Haine filmi üzerinden yapmayı hedeflediğim Wacquant okuması metninin araştırma ekseninde, gündemin etkisiyle Avrupa banliyöleri ve şiddet ilişkisi söylemleri paralelinde bir kayma yaşadığımı itiraf etmeliyim. Sarı yelek protestolarının Avrupa'nın bir çok kentinde yayılmaya başlaması ile Avrupa basınını takip sürecimin sonucunda yazı şekillenmeye başladı. Dolayısıyla başlangıçta bu şekilde kurgulanmamış bir araştırma yöntemi, yazım sürecinde ortaya çıtı. Bu noktada, yazı içinde değinilen Foucault'un söylemsel pratikler ve Bourdieu'nun sembolik şiddet kavramları çerçevesinde haber söylemine eleştirel yaklaşımımı ortaya koymaya çalıştım. 
Araştırmanın argümanı; Avrupa banliyöleri ile Amerikan gettolarının yapısal, tarihsel ve işlevsel farklılıklarından ötürü aynı kategorizasyon içinde ele alınamayacağı savının, Wacquant literatürü temelinde La Haine filmi üzerinden ilerleyen bir analizine dayanmaktadır. Bununla birlikte medyada ve politik arenada ortaya çıkan söylemlerin, bu iki olguyu aynılaştırmaya çalışması eleştirilmektedir.

\section{Sosyo-mekansal İnzivanın Analitik Arka Planı}

Sosyo-mekânsal inziva (İngilizce literatürde seclusion olarak geçen terimi bu metinde inziva olarak kullanılmaktadır), belirli toplumsal kategorilerin ve faaliyetlerin, fiziksel ve sosyal alanın ayrılmış ve kısıtlı bir kademesiyle birleştirildiği, oralarda tutulduğu ve izole edildiği süreçleri ifade etmektedir. Wacquant (2014) bunu iki alanda kavramsallaştırır; kırsal kesimde sosyomekânsal inziva, kentsel sosyo-mekânsal inziva.

Kırsal kesimde, mekânsal kapanmanın kurallarını belirleyen başlıca faktör, madun nüfusun işgücü olarak mi, yoksa işgal ettikleri araziyi tahliye etmek için mi kaldırılması gerektiğidir. Baskın grubun madundan işgücü olarak istifade edemediği durumlarda sömürgeci karşılaşmalarda olan bir tavırla, buradaki topluluğu yeniden gruplamak ve hareketsiz kılmak için tasarlanmış özel yasal ve geleneksel kurallar ile yönetilen genellikle sinırlandırılmış rezerv bölge olan bir rezervasyonun(Yerli Amerikalıların yaşadıkları durum örneği) ortaya çıktığını görürüz (Wacquant, 2014). Wacquant'in sosyo-mekânsal inziva diyagramında (bkz. Resim 1) toprak / işgücü ekseni boyunca sağ tarafa doğru hareket edildiğinde, madun nüfusların emek gücünü güvence altına almak ve şehire gelmelerini engel olacak iki tür kümelenme ile karşılaşıyoruz; göçmen işçiler için çalışma kampı ve mülteci kampi.

Wacquant (2014), kentsel sosyo-mekânsal inziva biçimlerini ise iki temel boyutta ele alır; ilki sınıf (pazar kapasitesi), etnik köken veya yerlerin prestij derecesine dayalı olup olmadığını temsil eden sosyal hiyerarşideki düzeydir. Bu sosyal hiyerarşi, toplumun en alt ve üstündeki inzivaya ayrılır. İkinci boyut, dışarıdan bir baskı ile veya kendiliğinden belirli bir alana kapanma durumunu ifade eden inzivanın seçime bağlı olup olmadığı boyutudur. Bu iki eksen tarafından belirlenen iki boyutlu uzayda tipik sosyo-mekânsal kümelenme biçimleri dağılmaktadır. Diyagramın sağ üst tarafındaki çeyrekte, seçim tarafında; sosyo-ekonomik bakımdan yüksek gelir grubunu temsil 
eden yerleşmeler görülmektedir. 1980'lerden sonra ortaya çıkan sosyal ve mekânsal hiyerarşinin tepesinde yer alan "kapılı topluluklar (gated community)" sosyal bakımdan homojen olan, suç, güvenlik endişeleri ile şekillenen ve ayrıcalıklı bir yaşam alanı vaat eden topluluk alanlarıdır. Tablonun üst kısmında diğerlerini dışlamak ve kendi kendini izole etmek için maddi ve sembolik sermayeyle donatılmış güçlü kişiler tarafindan kullanılan soylu faaliyetler görülürken, en altta ise yerinden edilmiş ve ekonomik ve kültürel sermayeden mahrum bırakılmış alt tabaka nüfusların faaliyetleri yer almaktadir.

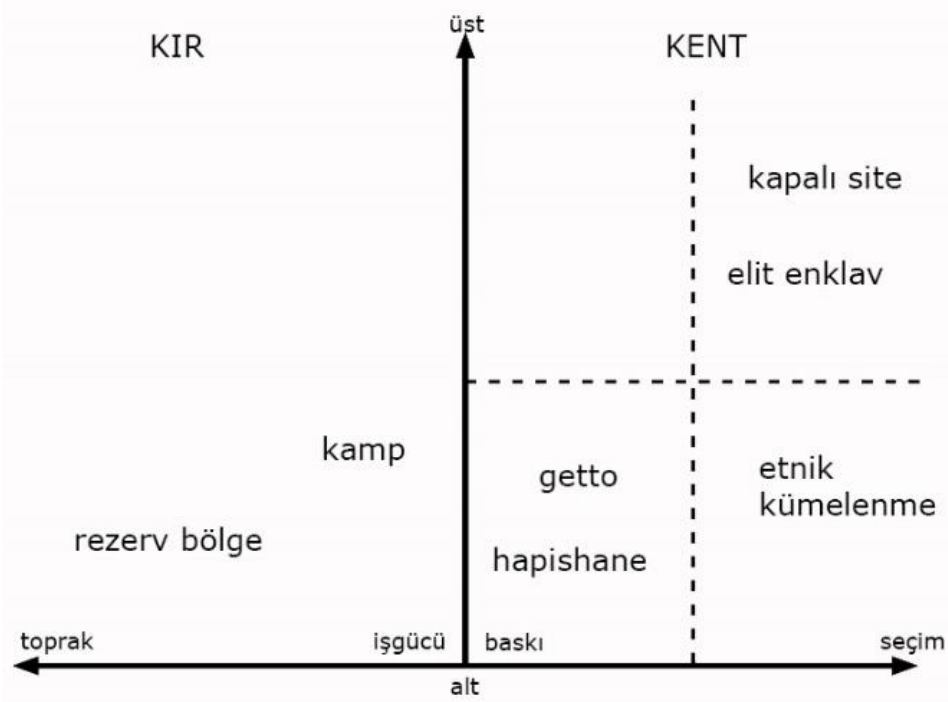

Resim 1. Wacquant'in sosyo-mekânsal inziva diyagramı(Wacquant, 2014)

Kentsel hiyerarşinin en altında yer alan sosyo-mekânsal inzivalar; etkisi yayılan iki büyük etno-ırksal form olan getto ve etnik kümelenmedir. Bunlar, bask1/seçim sürekliliğinin iki ucunda yer aldıklarından (Marcuse ${ }^{1}$ gönüllügönülsüz getto kavramı bağlamında her iki kümelenme de getto içinde ele alınmaktadır), farklı yapılara ve karşıt işlevlere hizmet ettikleri için birbirinden farklıdır. Mimari açıdan (beyaz) etnik bir kümelenme bir köprü ile temsil edilebilir, diğer taraftan (siyah) getto bir duvar temsili ile anlaşılabilir. Biri esnek ve geçici bir mekanizma iken diğeri esnek olmayan ve kalıcı bir

\footnotetext{
${ }^{1}$ https://www.unizo.be/images/res299713_17.pdf (Marcuse,1997; The Enclave, The Citadel and The Ghetto)
} 
araçtır. Gettoları, istenmeyen grupların hapsedildiği bir çeşit etno-ırksal hapishaneler olarak düşünebileceğimizi ifade eder Wacquant (2014).

\section{Medya ve Korku Çerçevesinde Sürgün Yerleri}

'kavramlar yanlış anlamalan düzeltebileceğgi gibi kötüleştirebilir, bunları giderebileceği gibi tetikleyebilir'

Wittgenstein

Foucault (2006), öznel deneyimin söylemsel olan ve olmayan pratikler ile iktidar tarafından nasıl kurulduğunu anlatırken; bilginin nasıl bu pratikler içinde kullanıldığının önemini vurgular. Bilimsellikle desteklenmiş söylemi; normal-patolojik ayrımı ile deliliği inşa etmesi üzerinden örnekler. Aynı örnek üzerinden başlangıçta var olan diyaloğun sonradan monoloğa dönüşmesi ve bunun toplumsal/kavramsal yarılmalara neden olduğunu ifade eder. Böylelikle Foucault'ya göre birey kimliğini belirlenen öznel deneyimler ile sinırlandırır. Medyada haber ya da tartışma programlarında istatistikler üzerinden konuşan konunun ehli uzmanların bilimselleştirdiği bir söylem pratiğinin oluşturulduğunu takip edebileceğimizi varsayıyorum. Bunu Bourdieu'nun simgesel şiddet kavramına dolaylı olarak bağlandığını düşünüyorum. Bourdieu gelişmiş toplumlarda bile başat tahakküm tarzının, açık baskı ve fiziksel şiddet tehdidinden simgesel manipülasyon biçimlerine kaydığını iddia eder (Swartz, 2011, s.120). Simgesel sistemlerin bilişsel ve bütünleştirici işlevlerinin yanı sıra Bourdieu'nun en çok üzerinde durduğu tahakküm araçları olarak işlevi önem kazanmaktadır. Hakim simgesel sistemler hakim grupların bütünleşmesini sağlarken, ezilen gruplar için ayrım ve hiyerarşi yaratır ve tahakküm altındakileri, toplumsal ayrımların mevcut hiyerarşilerini kabul etmeye zorlayarak toplumsal tabakalaşmanın meşruluk kazanmasını sağlar. İdeoloji, ya da simgesel şiddet, ekonomik ve siyasi iktidarı kılık değiştirmiş, sorgusuz sualsiz kabul edilen biçimler altında temsil ederek toplumsal dünyayı anlamayı ve uyarlamayı sağlayan araçları dayatma gücüdür (Swartz, 2011, s.120-9). Bu doğrultuda çalışmada, Avrupa'da yükselen gettolaşma endişesinin söylemsel olan ve olmayan pratikler çerçevesinde nasıl inşa edildiği ve sembolik şiddet kavramı kapsamında ortay çıkan peyzajı resmedilmektedir. 
Wacquant (2015, s.158), Kent Paryaları kitabında Cohen'e referansla "banliyölerle ilgili ahlaki bir paniğin hızla yükselişine, billurlaşmasına" tanıklık ettiğini ifade eder. Doksanlı yıllara kadar Fransa politika ve medyasında dikkat çekmeyen, kent çeperlerindeki yıkık dökük toplu konut projeleri, Kuzey Afrikalı gençlerin başını çektiği sokak protestoları ve eylemleri gündeme gelir. Banliyö konusu şehir plancilarından, siyasetçi ve medyadakilerin ana ilgi konusu olmaya başlarken, Amerikan kökenli getto kavramı ile özdeşleştirilmeye başlanır(Wacquant, 2015) ${ }^{2}$. Medyanın kamu düzeni ile ulusal toplumun bütünlügüne karşı banliyölerin gittikçe daha büyük bir tehdit oluşturduğu söylemi ile banliyölerin etnik gettolara dönüştüğü ç1ğırtkanlığı yapılmaktaydı. Wacquant, 1990 sokak eylemlerinin ardından benzer içerikte birçok haberin art arda köşe yazılarında baş gösterdiğini ifade eder. 1991 yılında Fransız Hükümeti, Anti-Getto yasasını yürürlüğe koyar. Ortaya çıkan görüntülerin altında Fransa' daki kentsel eşitsizlik yatmaktadır. Medya söylemi ve politik dil ile oluşturulan panik havasında tehdit olarak görülen şiddet değil; Avrupa banliyölerinin Amerikan tarzı gettoların yapısına kayma tehlikesi olarak görülmektedir (Wacquant, 2015, s.164). Banliyöler ile ilgili benzer yaklaşımdaki haberleri 2005 yılı olayları sonrası gazete başlıklarından da görmek mümkündür (Resim2).

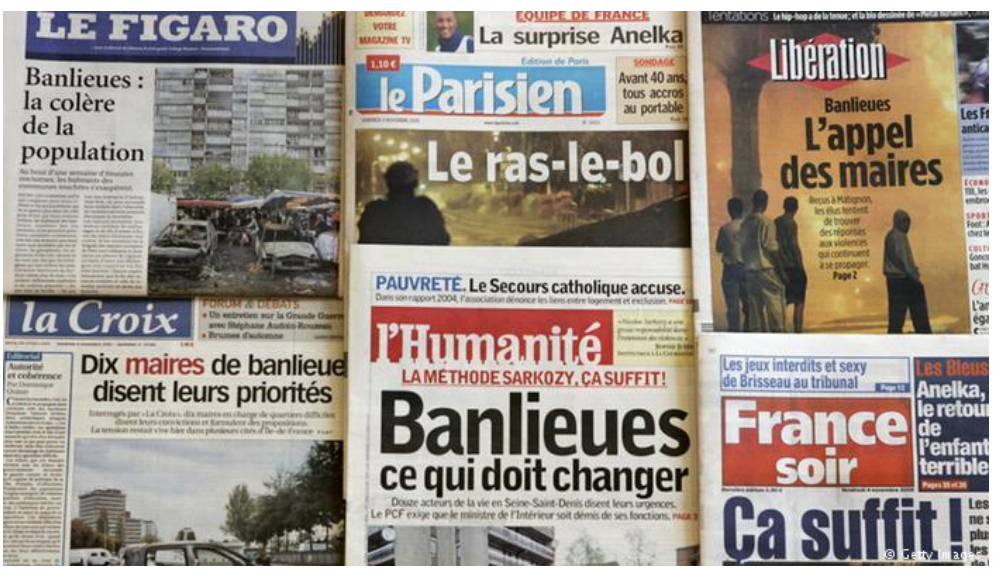

Resim 2. 2005 Fransız gazete başlıkları ${ }^{3}$

\footnotetext{
${ }^{2}$ Wacquant; banliyölerin gettolaşması konusunun bu tarihten önceye dayandığını açıklar.

${ }^{3}$ https://www.dw.com/en/acquittals-in-paris-banlieues-police-trials/a-18457173
} 
Bu noktada Amerikan gettosu ile Avrupa Banliyösünü yapısı ve işlevleri doğrultusunda araştıran Wacquant'ın ikisi arasındaki farklılıkları nasıl ortaya koyduğunu aktarmaya çalışacağım. Öncelikle benzerliklerinden söz etmek gerekirse; nüfus yapısındaki benzerlik; yüksek yoğunlukta etnik farklılıkları içermesi yönünde görülür (bir tarafta siyahlar, diğer tarafta göçmenler). Burada yaşayan ve dişarıda olup buradan korkanlar için bu yerleşimleri tanımlamalarındaki algilar ortaktır. Bununla ilişkili olarak getto ve banliyöler üzerine yapıştırılan yaftalamaları burada yaşayanların sürekli üzerlerinde taşımak zorunda olmaları benzerlik gösterir. Yine buna bağlı olarak bu yaşam alanlarından kaçma istekleri benzerdir. İşsizlik durumları ve yoksulluk seviyeleri benzerlik gösterir. Diğer yandan aynı sıklette bulunmayacak nüfus büyüklükleri bu iki tipin işlevsel ve ekolojik farklılıklarını ortaya çıkartır. Bunların başında gettoların homojen, banliyölerin heterojen yapısı gelmektedir(ama bu durum banliyölerin gettolaşması söylemine etki etmemiştir!). Gettoların aksine kendi kurumlar ağını geliştirmiş değildir banliyöler. Dışarıya kapalı gettoların tersine, kent dokusuyla alışverişte bulunan, gettolar gibi kendine yeten bir işlevi olmayan, kendi sosyal adaletlerini sürdürülebilecek kadar çok işlevli topluluklar olmayan banliyöler, daha çok yerleşim adalarıdır. Refah ve yarı refah devleti politikaları, sosyal yardımlar ve hizmetler bakımından da farklılıklar olduğu anlaşılmaktadır. Suç ve tehlike bakımından gettolarda kamusal alan fiilen ortadan kalkmış görünürken, banliyölerde medyanın yönlendirmesinin dışında aniden patlayan bir şiddet durumunun olmadığını ifade eder Wacquant (2015, s.178). Bu durumu getto okullarında meydana gelen silahlı saldırıları örnek vererek açıklar. Mesken stoku karşılaştırması ve fiziksel çevre koşullarının da farklılık gösterdiği ifade edilmektedir.

Komünal gettosunda siyahlar ve beyazlar arasında kapsamlı karşıtlıklar kök salmış, bu dışlama süreci devletin organları ve politikaları tarafından hem maddi hem de simgesel olarak desteklenmiştir. Fransa banliyölerinde devletin tutumunun daha yara sarıcı ve koruyucu olduğunu ifade eder Wacquant (2015, s.257-58). Diğer yandan uluslararası bir organizasyon olan OSF (Open Society Foundation), Avrupa banliyölerinde yaşayanlara yönelik olarak medyada suçlayıcı bir dil kullanıldığını ifade ederken, bu alanlarda yaşayan insanların işsiz ya da az ücretli işlerde çalıştığını, güvencesizlik içinde oldukları, eğitim ve sağlık gibi temel hizmetlerden tam olarak faydalanamadıklarını ve dışlanmış hissettiklerini belirtir. Organizasyonun yapmış olduğu alan çalışmalarına göre; burada yaşayanların yurttaşlık haklarını istedikleri, aktif olarak politika yapmak istedikleri ve sosyal anlamda 
yeni insanlara açık oldukları ve aralarındaki sosyal ilişkilerin güçlü olduğu görülmektedir. ${ }^{4}$

Medya ve politik arenada sürekli dile getirilen gettolaşma söylemine cevaben; Wacquant (2014), banliyölerin neden gettolaşamayacağını maddeler halinde açıklar: Birincisi, gettolaşma, sınırlı bir kategorinin üyelerinin, kendileri için ayrılmış ayrı bir alanda yaşamaya zorlanması anlamına gelir ve bu da mekanik olarak yükselen etnik homojenliğe dönüşür. Fakat Paris Kırmızı Kuşağı' nın terkedilmiş ilçeleri ve Fransa'nın hassas banliyölerinin, son yirmi yılda daha az homojen hale geldiğini ifade eder. Gettolaşmanın ikinci bir göstergesi, artan örgütsel yoğunluğun göstergesidir: Ayrılmış bir yerleşim biriminde damgalanmış bir kategori, enformel ve resmi örgütlenmelerin büyümesinde ve artan farklılaşmasında kaydedildiği gibi, onu kendi kurumları ile dolduracaktır (Ancak, Batı Avrupa, İngiltere Midlands'tan Alman Ruhr'a, Kuzey İtalya şehirlerinin bozulmuş mahallelerine kadar işçi s1nıfı bölgeleri, yerel kuruluşlardan çok, bu bölgelerdeki mevcut dernekler devlet bürokrasisine dayanan kamu bürokrasileri ve topluluk kurumlarıdır). Üçüncüsü, gettonun damgalanmış nüfusunun çeşitli bileşenlerini kapsayan ortak bir kimlik oluşturma olgusunun ortaya çıkışını teşvik eden bir kültürel enerjinin var olmasıdır (Yine, Batı Avrupa'nın işçi sınıfı bölgeleri, bu şemadan uzaklaşıyorlar. Wacquant bunu şu örnek ile açıklar; La Courneuve'de, Les Quatre mille kiracılarına cami inşa etmek için bir şehir arsasının ücretsiz kullanımı verilmiş ancak Müslüman inanca sahip farklı etnisiteden nüfusların- Faslılar, Cezayirliler, Tunuslular, Türkler, Çin gibi- her biri ayrı ibadet yeri istedikleri için projede asgari bir anlaşmaya varamamışlardır). Gettonun dördüncü bir özelliği, sınırları ve gelirleri ne olursa olsun, sınırlarının aşılmaz olmasıdır (Cezayirliler üzerine yaptığı gözlemlere dayanarak Wacquant, farklı alanlara, kentin merkezine göç eden ya da farklı sınıf yapısına geçen ve kentsel alandaki dağınık olarak, benzer sınıf seviyesindeki "beyaz" Fransız ailelerle karıştıklarını tespit eder).

Özetle, Avrupa metropolünün azalan alt sınıf mahalleleri, daha heterojen, etnik ve daha az yoğun örgütsel hale gelmektedir; geçirgen sınırlara sahip olan bu yerleşmeler; paylaşılan bir kültürel kimlik oluşturmayı başaramamışlardır. Her dört açıdan da, Avrupa banliyölerinin, gettonun sosyomekânsal dinamiklerine uymadığı ifade edilir. Bu yüzden onlara Avrupa

\footnotetext{
${ }^{4}$ https://www.opensocietyfoundations.org/voices/understanding-europe-s-whiteworking-class-communities
} 
kentinin "Amerikanlaşması" nın moda tezinin savunucularına yönelik olarak Wacquant, anti-getto terimini ortaya atar; yirmi birinci yüzyılın başlangıcında Batı Avrupa'da kentsel inzivayı tanımlamak için gettolaşma dilinin son derece yetersiz olduğunu iddia eder. Paris'teki damgalanmış mekanlar üzerine etnografik araştırmalar yapmış olan Castaneda (2012, s.159190),Wacquant'ın banliyölerin yapısal olarak siyah gettolardan çok farklı olduğunu, kısmen de kendi alt kültüründen ve gayri resmi kültürel ve politik kurumlarından yoksun oldukların ileri sürdüğü sava şöyle bir eleştiri getirmektedir: Büyüyen Fransız rap endüstrisi, banliyö esinli film ve tiyatro, banliyö gençliğinin özel dil ve giyim tarzı, Conseil Representatif des AssociationsNoirs (CRAN) ve Indigènes de la République gibi hareketler ile derneklerin büyümesi gibi özelliklerin Wacquant'in hipoteziyle çelişebileceğini düşünmektedir. Dahası, etnik örgütlerin görece zayıflı̆̆ı ve eşgüdümlü eylemler, görünürdeki azınlıklara yönelik ayrımcllık eksikliğinden ziyade, Fransız cumhuriyet yasaları ve değerleri ile daha fazla ilgisi olabilir (Castaneda, 2012).

Balibar (2007) içsel dışlamayı aktardığı yazısında, 2005 yılında Fransız banliyölerinde yaşanan isyanlar sırasında "dışlama" kavramının tartışıldığından bahseder; Castel (2007)'in dışlama kategorisinin, en azından başlangıçta, polise karşı mücadele eden çoğunlukla göçmen kökenli (yani, Afrikalı ve Kuzey Afrikalı) fakat aynı zamanda Fransız yurttaşı olan, işsiz gençlerin durumunu betimleye uygun olmadığını aktarır. Bunun, Fransız banliyölerinin $\mathrm{ABD}^{\prime}$ de olduğu gibi tam olarak gettolar olmadığını ileri süren Loic Wacquant'in saviyla uyuş̧tuğunu ifade eden Balibar (2007) Castel' in sözlerini şöyle aktarır: "Banliyö bir getto değildir, banliyönün genç müdavimleri "dışlanır", şayet kavrama kesin bir anlam verilecekse: dişlama, tam anlamıyla nüfusun iki ayrı kategoriye bölünmesi demek iken, "dışlanan" toplumsal oyuna dışsal olacaktır zira kolektif sosyal yaşamda bir rol oynamak için gerekli olan bir hiçbir hakka, kapasiteye ve kaynă̆a sahip değildirler... Banliyödeki gençler Fransız ulusuna aitliği destekleyen politik yurttaşlık ve toplumsal yurttaşlık gibi birçok ayrıcalığa hak kazanır. Etnik kökenlerinden bağımsız olarak projelerdeki çoğu genç, Fransız yurttaşıdır. Bu yüzden ilke olarak en azından vatandaşlık hakkı yaşına geldiklerinde, yasalarca siyasal haklara ve eşit muameleye sahiptirler..." (Sar1, 2011).

Balibar (2007)'a göre Fransız banliyölerindeki genç isyancılar örneğinde sınıf ve ırk ayrımcılığının radikal biçimler aldığını ifade eder: "sımıf ayrımcılı̆̆ı, işsizlik ve güvencesiz iş arasında yabancılaştırıcı bir tercih halini almışken, ırk ayrmmcilığı ise göçmenlerin oğul ve torunlarmın yasal statülerinin açıkçelişkisi içerisinde ebediyen "yabancllar" ve göçmenler" olarak temsil edildiği "soy kütüksel 
bir düzen" biçimini almıştır. Bu toplumsal bir kültürel aşă̆ıllk imgesi ile bir yabancı doğrudan potansiyel bir düşmanmış gibi -ki tüzel terimlerle yabancı bile olmayan- genç Afrikalılarn ve Araplarm temsil ettiği yurttaş güvenliğine yönelik tehditle de benzeşir...". Balibar (2007), Avrupa nüfusunun bir parçası haline gelmiş ötekinin, "dişlanan" kategorisinin fark gözetmeyerek genelleştirilemeyeceğini iddia eder. Diğer taraftan çoğu kez, göçmenler ve onların torunlarının kendilerini farklı yerel ve küresel dışlama biçimlerinin içinde bulduğunu ifade eder (Sarl, 2011).

La Haine (Protesto) filminde banliyödeki heterojen etnik yapıyı görmek mümkün. 1995 yılında Kassovitz tarafından çekilmiş film, Fransa'daki banliyö ve sınıf meselesini irdeler. Afrika kökenli Hubert, Yahudi Vinz ve Arap Said'in başkahramanları banliyö gençliğinin heterojen yapısını yansıtmaktadır. Bu heterojen topluluk içinde sosyal bağların da çok kopuk olmadığ1 görülmektedir. Diğer taraftan içsel dişlamanın sonucu olarak banliyöde kendi içinde de ikincil bir dışlamaya ev sahipliği yapabileceğini cinsiyet üzerinden söylemek mümkün. Film boyunca cinsel içerikli küfürler bolca geçmesine rağmen filmde kayda değer bir kadın figürünün olmaması; banliyö yaşantısı temsilinde kadına yönelik bir dışlamaya gönderme yapıyor olabilir.

Kültürel çalışmalar altında yabanclaşma kavramı çerçevesinde, kültürlerin (alt/üst) temsil biçimlerine ilişkin özellikle medya ve müzik üzerinden yapılan araştırmalara (Adorno'dan Goodwin ve Hall'ın başını çektiği Birmingham Okulu Kültür Çalışmalarına kadar geniş bir zaman dilimine yayılan çalışmalar) bakıldığında temsilin bir direniş temsiline hangi formlarda dönüştüğünü görebilmekteyiz. La Haine filminde grupların eylem, giyim kodları, madde kullanımları, kullandıkları argo dil, dinlikleri müzik ve dans gibi gündelik pratiklerinde görülen rutinler; işsizlik ve yabancılaşma gibi nesnel koşullara karşı sembolik ve imgesel tepkiler olarak ortaya çıkmaktadır. ${ }^{5}$ Film boyunca ara ara ön plana çıkan sokak müziği olarak bilinen hiphop müzikler eşliğinde dans eden gençleri görürüz. Bunun yanında arka fonda duyulan caz, fank, reggie tarzı müzikler; banliyö yaşamının kültürel kompetanı gibi algilanır. Bir yandan banliyö mekânın duvarlarındaki grafitiler buradaki gençlerin kültürlerini gösterme şekillerinden biri olarak karşımıza çıkar. Filmde banliyölerin fiziksel yapısı hakkında da bilgi sahibi olabiliyoruz;

\footnotetext{
${ }^{5}$ Bu savın menşeindeki etnografik çalışmaları içeren "Ritüeller Yoluyla Direniş"(Hall ve Jefferson, 1976) kitabında konu detaylı bir şekilde ele alınmıştır.
} 
planlı yerleşme ve 5-6 katlı dikdörtgen yapı bloklarından oluşan modern mimarlığın tipik örneği bir yerleşme alanında eğlenmek için sokakların değil kapalı alanlar ya da çatının kullanıldığı görülür. Sokaklar, çatışmaların izini taşıdığından sürekli bir tetikte olma durumunu akıllara kazır.

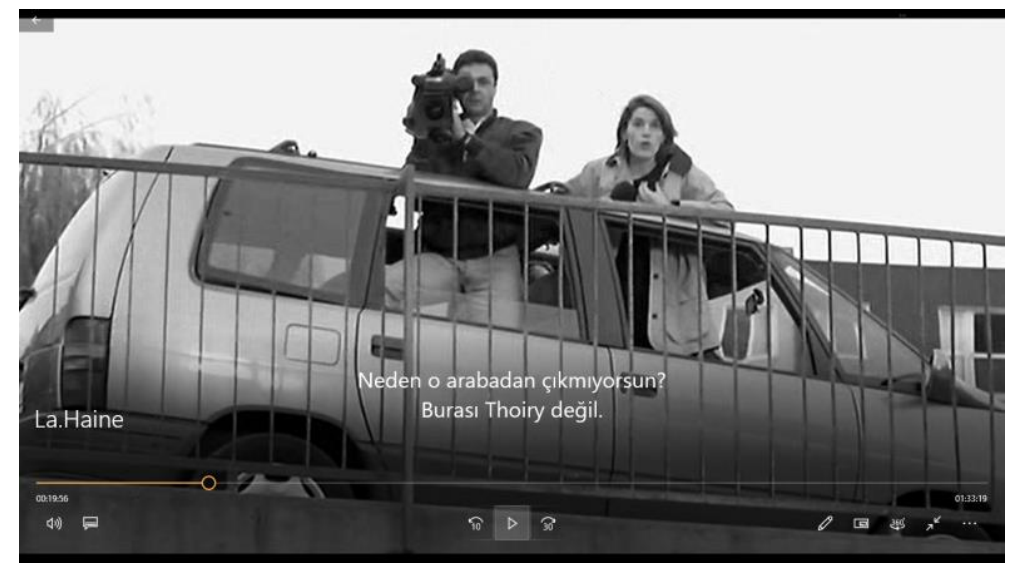

Resim 3. La Haine-basın algisı

Medya söylemleri bağlamında üzerinde durulması gereken bir diğer önemli konu; Bourdieu'ya referansla 'sınıf kavramının yanlış tanınma' çerçevesinde algının dayatılmasıdır. İleri toplumlarda, simgesel manipülasyon uğraşı genelde temsil kabiliyeti olan uzmanlar tarafından tekel altına alınırsendikacılar, siyasetçiler, devlet idarecileri, anketörler, gazeteciler ve entelektüeller (Wacquant, 2013). Ve bunun için de simgesel şiddetin önemli araçlarından biri olan televizyon kullanılır. La Haine filminde Afrika kökenli genç Abdel'in polis tarafından sokak eylemleri sırasında öldürülmesinin televizyonda yanlı bir haber olarak verilmesi ile banliyödekilerin buna tepkisi, temsil problemini de ortaya koyar. Gerçekliğin tüm Fransa'ya tek taraflı ve suçlu gösterilerek veriliyor olması Bourdieu (1991)'nun bahsettiği simgesel manipülasyona işaret etmektedir. Mahalleye röportaj yapmak için gelen gazetecileri kovan gençler, taraflı olduğunu gördükleri medyanın kendilerini anlamaya çalışmak için değil, hayvanat bahçesine ziyarete gelmiş gibi davranmalarına tepki göstermektedir (Resim 3). Temsil ortamının demokratik olmadığı bir ortamda kendilerini gündelik ritüelleri içerisinde söz ve davranış kalıpları biçimleriyle ifade etmelerini sonucunu doğurmuştur. Ötekinin-ötekileştirilenin mekânı olarak görülen banliyöde temsili demokrasinin kendilerini temsiline olan inancın kalmadığı görülmektedir. 
Lazzarato (2015, s.220), 20.yüzyılın tamamına yayılan süreç içinde politik partiler ve sendikalar, devlet kurumlarının bütünsel birer parçası haline geldiklerinden dolayı temsili demokrasinin giderek devlet mekanizmasına dönüştüğünü ifade etmektedir. Dünyanın neredeyse tamamında patlak veren protestoların, temsili demokraside başka alternatifin mümkün olmadığ1 gerçeğini ortaya koyduğunu iddia eder. Protestoların menşei getto-banliyö gençleri ya da kent paryalarının sosyo-mekânsal kümelenmelerinin yer aldığı kentsel mekânlar olarak görülmektedir.

\title{
Gettoya geri dönüş: Devlet Politikaları ve Toplumsal yaşam Çerçeve- sinde Gettodan Hipergettoya, Banliyöden Antigettoya Sürgün yerleri
}

\begin{abstract}
...Sorunlar özellikle mahrum edilmiş konut alanları ile bağlantılıdır. Günlük dilimizde getto denen bölgeler. Hükümet yirmi dokuz getto alanını belli başlı zorluklara göre tanımlamıştır. Bunlar, sakinlerin büyük bir kısmının işsiz olduğu alanlardır. Bir suçlu geçmişi olan birçok insanın yaşadığ̆ ve göçmen kökenli birçok Danimarkalının yaşadığ yerlerdir. Kararlı harekete geçmeliyiz. Gettoların bazı kısımlarında egemen olan tahammülsüzlüğe karşın, yanlış hoşgörülü̈lüğe son verme zamanı gelmiştir. Açıkça konuşalım: Danimarkalı değerlerin să̆lam bir zemine sahip olmadığı yerlerde, normal çözümler tamamen yetersiz hale gelecektir...
\end{abstract}

(Danimarka Meclis açılış günü) Rasmussen (2010) ${ }^{6}$

Danimarka'nın merkez să̆ hükümeti, 2030 yılına kadar sözde "paralel toplumları" ortadan kaldırmak amactyla, daha fazla sayıda göçmen ve daha fazla işsizliğe maruz kalan vandalizm ve hırsızlık gibi suçlara yönelik cezayı iki katına çıkarmak istiyor. Aralık ayında, hükümet "getto" listesini sunarak göçmenlerin ve onların torunlarının oranının yüzde 50'nin üzerinde olduğu, işsizlik oranmın yüksek olduğu ve başka şeylerin yanı sıra çok sayıda ceza kanunu mahkûmiyetinin bulunduğu 22 yeri vurguladi.

Breitbart $^{7}$

Popülist Danimarkalı Halk Partisi'nin (DF) toplumsal olarak marjinalize olmuş bölgelerde yaşayan gençlere sokă̆a çıkma yasağı koyma önerisi geldi...

The Local News $(2018)^{8}$

\footnotetext{
${ }^{6}$ https://www.citylab.com/equity/2018/07/denmarks-ghetto-plan/564296/

${ }^{7}$ https://www.breitbart.com/europe/2018/02/28/danish-government-double-punishments-largely-migrant-ghetto-areas/

${ }^{8}$ https://www.thelocal.dk/20180105/danish-populists-curfew-plan-for-ghettos-facescriticism-cross-aisle-criticism
} 
1960 ayaklanmaları sonrası Amerikan gettosu içe doğru çökmüştür. Bunda etken olan üç önemli faktör vardır; ekonomik (sanayinin yerini hizmet sektörüne bırakmaya başlamasıyla ucuz işgücü kaynağı olarak görülen getto sakinlerini gereksiz! hale getirdi); demografik ve politik (1970'lerde ekonomik kriz etkisiyle merkezden banliyöye doğru beyaz göçü) ile Siyah Güç Hareketi (insan hakları hareketleri içinde ortaya çıkan radikal, beyaz egemenliğe karşı harekete geçilmesi). Bu üç faktör, gettoların kendi içine doğru çökmesine neden oldu; bu da hiper-getto ve orta sınıf siyahların oturduğu uydu-mahallelerden oluşan ikili bir kümelenmeye yol açtı. 1910'larda yükselen 60 'larda yok olan komünal gettolardan hipergettoları ayıran üç özellik var; birincisi, hipergettonun içerdiği emek gücü; ihtiyaç fazlasına dönüştügü için ekonomik bir işleve sahip değildir. İkincisi, ekonomik fazlalık, yeniden sosyal ayrımcılığa ve siyah burjuvazinin buharlaşmasına yol açmış, böylece hiper-getto hem irk hem sınıf temelinde çifte dışlanmanın yaşandığı sosyo-mekânsal bir izolasyon olarak ortaya çıkmıştır. Üçüncüsü ve sonuç olarak, egemenliğe karşı tamponlama ve gündelik yaşamın çerçevesini sağlamada kullanılan içe doğru büyümüss paralel kurumlardan sıyrılmıştır (Wacquant, 2014).

Atlantik'in diğer tarafında 1970'lerin ortalarından sonra Batı Avrupa kentinin çeperlerinde azalan işçi sınıfı bölgeleri, gerçekte hem işgal hem de etnisite açısından karma alanlar oldukları zamanlarda medya ve politika tartışmalarında "göçmen gettoları" olarak yaygın bir biçimde tasvir edilmişlerdir. Çok düşük yerel istisnaların dışında, Fransa'nın alt sınıf banliyöleri çoğunlukta Fransız olan ve farklı uluslardan gelen sakinlerden oluşan nüfusları içermektedir. Tarihsel olarak, fabrika işçiliği ile bağlantılı ücret emek, belediye hizmetleri ve mavi yakalı mahalle ve aile hayatı dünyasının sıkı entegrasyonu ile karakterize edilmiştir. Ancak yerel yönetim ve topluluk arasındaki sıkı ilişki, sanayisizleşme, kitlesel işsizlik, değerli sosyal pozisyonlara ulaşmada önem kazanan okullaşma ve devlet politikaları baskıları altında çözülmüştür (Wacquant, 2014).

Sonuç olarak, Amerika gettosunda irka dayalı sosyo-mekânsal izolasyonun daha sonra sınıf eksenine kaydığı ve hiper-gettoya dönüştüğü, ekonomik, eğitim, sağlık, konut politikaları aracılığıyla devlet tarafından bölgesel eşitsizliğin derinleştirildiği görülürken; Avrupa banliyölerinde sınıf öncelikli sosyo-mekânsal izolasyonun sosyal koruma ve kentsel hareketleri denetlemeyi amaçlayan müdahaleler ile devlet tarafından marjinalliğin kısmen hafifletildiği görülür. Atlantik'in her iki tarafında, kentsel marjinalliğin oluşmasında büyük tasarımcının devlet olduğu anlaşılmaktadır. Devlet, 
sosyo-mekânsal izolasyonun parametrelerini belirleyen kurumdur. Kentsel hiyerarşideki alt ve üst arasındaki mesafenin boyutunu; kent planlama, ekonomik düzenleme, maliye politikası ve altyapı yatırımlarından, konut, eğitim, sağlık, refah ve polislik gibi merkezi kamu mallarının mekânsal olarak farklılaştırılmış kaynağına kadar çeşitli programlarıyla bunu belirler (Wacquant, 2015).

Standing (2014), piyasayı, Darwin'in 'güçlü olanın hayatta kalması' metaforunun vücut bulmuş hali olarak tanımlar. Neoliberal devlet, rekabetçiliği desteklerken, piyasa güçlerini sekteye uğratan toplumsal herhangi bir şeye karşı durması bakımından Darwinci bir devlettir. Neoliberal devlet gücünü hukukun kolektif eylemlerin azaltılmasına dayalı hukukun müdahalesine dayanarak sürdürür. Bu müdahale, Wacquant'ın 'sapkın kategorilerin (sokak serserileri, işsizler, hirsızlar, karakter sorunu ve davranış bozukluğu sergileyen kaybedenleri tanımlar) kamusal alandan afaroz edilmesi' dediği sürece kadar uzar (Standing, 2014, s.221). Standing (2014), 2008 krizinden bu yana hükümetlerin, küresel piyasa ekonomisinin kurbanlarını-ki bunlar; göçmenler, sosyal yardım alanla, suçlular ve engelliler- şeytanlaştırdığını iddia eder. Bunlar politik demeçler ve basından takip edebilir (Bir yandan da Avrupa İnsan Hakları Mahkemesi'ne Avrupa ülkeleri aleyhine gelen "nefret söylemi" altındaki başvuruların 11 Eylül sonrası İslam dini ağırlıklı olduğu gözlenmektedir).

21. yüzyıl kent marjinalliğini ileri marjinallik olarak tanımlayan Wacquant (2015, s.259-74)'a göre; post-Fordist sürecin ücretli emeğinin örgütsüzleşmesi ve güvencesizliği, küreselleşen ekonomiden kopuş, mekânsal damgalamaya maruz kalma, toplumsal ortaklıkların zayıflaması ile uzamlaşan (tekinsiz boşluk bölgeleri) mahalin çözülmesi, hayatta kalabilmek için gayri resmi sosyal yardımlara bel bağlanamayacağından yasa dışı işlere yönelme ile yaşanabilir hinterlantın yok oluşu ve nihayet sınıfların çözülmesi ile ortak kader algısı yaratan dil ve simgeler repertuarından yoksun kalarak toplumsal parçalanma yaşanmasl; yeni kent paryalarının temel niteliklerini oluşturur. Kent paryalarının (outcasts) yeni ortaya çıkan biçimi olarak ileri marjinallikle başa çıkma çabalarında ulus-devletin üç siyasi seçenekle karşı karşıya olduğunu ifade eden Wacquant (2015, s.303-304) bunları şu şekilde

\footnotetext{
${ }^{9}$ Konu ile ilgili yapılmış bir çalışma; https://www.regent.edu/acad/schlaw/student_life/studentorgs/lawreview/docs/issues/v25n1/04Kiskavol.25.1.pdf
} 
açıklar; hareketsiz orta yol seçeneğinde refah devletinin mevcut programlarını derlemeyi ve hayata geçirmeyi içerir ve marjinalleri desteklemeyi hedefler; gerileyici ve baskıcı bir çözüm olarak yoksulları içinde hapsedildikleri yaftalanmış mahalleler ya da hapishanelerde cezai önlemlerle tutarak yoksulluğu suç haline getirmek (altmışlı yıllar getto ayaklanmalarından sonra $\mathrm{ABD}^{\prime}$ de ortaya çıkan hapishane sayısında ve içerdiği zenci nüfusundaki artış-Foucault'un söylemsel olmayan pratikleri bağlamında hapishane sayılarında artışın öznelliği nasıl disipline ettiğinin örneği olarak görmek mümkün- bu politikanın uygulandığını gösterir); üçüncüsü ilerici tepki biçimi olarak sosyal devletin kapsamlı bir şekilde yeniden yapılandırılması ile sosyal devlet mottosunun ileri uygulamaların içermektedir. Günümüz Avrupa'sının giderek cezai devlete dönüşerek ileri marjinallik ile başa çımaya çalıştığına tanıklık ederiz. Bu noktada Wacquant Avrupa Birliği ülkelerinin çoğunda hapsetme oranlarının olağanüstü yükseldiğini ve bu yükselişte Avrupalı kökenli olmayan nüfusun ağırlıkta olduğunu ifade etmektedir (Wacquant, 2015, s.304).

Wacquant, "Neoliberal Şehirde Marjinallik, Etnisite ve Cezalandırma: Analitik Bir Kartografya" başlıklı metninde; cezalandırma ve ırksallaştırma arasındaki bağlantıyı nasıl keşfettiğini şöyle açıklar; "bölgesel damgalamayı ileri marjinalliğin ayırt edici özelliklerinden biri olarak teorileştirmeseydim ve ardından hipergetto ile hapishane arasındaki işlevsel ve yapısal paralelliğin farkına varmasaydım, küçük düşürmenin birbirine akraba biçimleri olarak cezalandırma ve ırksallaştırma arasındaki gizli bağlantıları tespit edemeyecektim" (Merrifield, Negri, Bayat, Harvey, Wacquant, Amoros, Torlak, 2014, s.124). Irksallaştırma ve cezalandırma arasındaki bağlantının yoğunlaştığını medyadan takip etmek mümkün. 2010 yılında yaptığı açıklamada kaçakçılara ve suçlulara karşı savaş ilan eden Fransız Devlet Başkanı Sarkozy (Merrifield vd., 2014, s.113) bir polis şefini vali olarak atayacaktır. Sarkozy istenmeyen yabancıları doğrudan suçla bağlantılandırıyor; çözüm olarak da adalet sistemi eliyle ileri düzeyde (vatandaşlıktan ç1karmaya kadar) ve açıça ayrımcı cezaları işaret ediyordu. Benzer söylemler Avrupa'nın farklı ülkelerinden de gelmekte. Örneğin yukarıda yer alan gazete başlıklarında; Danimarka'da getto listelerinin açılanmasi ${ }^{10}$, bu alan-

\footnotetext{
${ }^{10} \mathrm{http}: / / c p h p o s t . d k /$ news/danish-municipality-splitting-up-housing-area-to-get-iton-ghetto-list.html

http://www.irr.org.uk/news/denmarks-ghetto-list-must-be-scrapped/
} 
larda yaşayan gençlere yönelik sokağa çıkma yasağı ve cezaların arttırılması gibi önerilerin devlet organları tarafından medyaya çıkmış yorumları yer almakta. Belanın kaynağı olarak algılanan ve damgalanan banliyö sakinleri için bu alanlarda yaşamanın zaten kısıtlı olan iş bulma durumunu ek olarak olumsuz etkilediği (Wacquant, s.265) ve bu durumun da yasadış1 işlere yönelmelerine sebep olduğu anlaşılmaktadır.

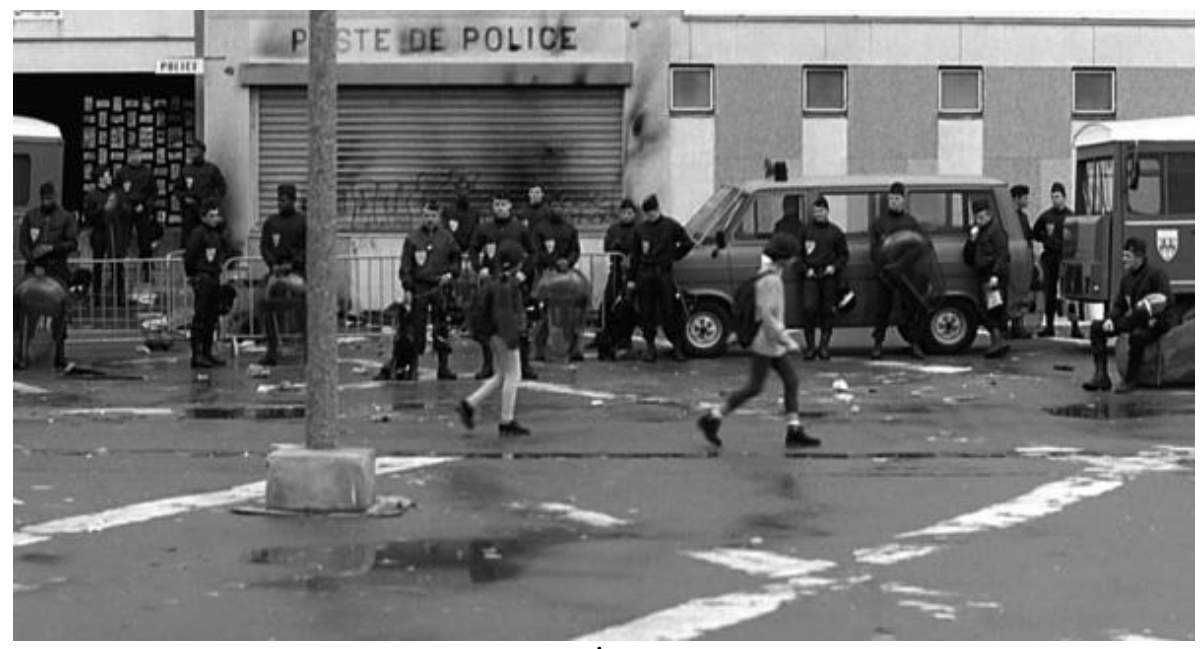

Resim 4. La Haine -İstisna olarak Banliyö

La Haine filminin geçtiği banliyöde, Agamben (2013, s.29)'in istisna kavramını açıklarken kullandığı duruma uygun düşen; askıya alınmış bir demokrasinin/hukuk düzenin var olduğu görülmektedir (Resim 4). Polisin uyguladığı şiddete karşı hukuki yolların aranma düşüncesine bile gidilmemesi; istisna/olağanüstü halin gündelik hayatın içinde nasıl normalleştirilmiş olduğunu göstermektedir. Agamben'e göre kriz durumu söylemi altında meşrulaştırılmaya çalışılan istisna hali, yasasız bir yasa gücünün söz konusu olduğu kuralsız bir alandır. "Bu düşen bir toplumun hikayesidir; kendini rahatlatmak için buraya kadar her şey yolunda diye tekrar eder, önemli olan düşüş anı değil çakılma anıdır" cümleleri filmin çekildiği 90'lı yıllardaki Fransa sokak hareketlerine referans veren önemli bir sözü olarak karşımıza çıkar. Yine dönemin ırkçı politikaları ile bilinen Le Pen'e gönderme yapan bir sahnede; "sistemin ürettiği adamlar sistemin asansörünü kullanır ve arıza çıkarınca ayaklanır, Le Pen'e oy verir ve ırkçı değildir; işte 
en tehlikelisi bunlar" açık bir sistem eleştirisi vardır. Başka bir sahnede "özgürlük, eşitlik, kardeşlik" mottosunun gerçeklikle ilgisi olmaması ile dalga geçilir. Aslında banliyö gençlerinin temel derdinin sistemle olduğu anlaşılmaktadir.

\section{Genel Değerlendirme}

Bu sabah sokă̆a çıkma yasă̆ıyla uyandım;

Tanrum, esirdim de, evet

Etrafimdaki yüzleri tanıamadım; Hepsi gaddarlık üniformalarını giymişti

Daha ne kadar nehir geçeceğiz,

Patronla konuşmak için?

Elimizdeki her şeyi kaybetmiş gibiyiz;

Bedelini cidden ödemiş olmalıyız.

Bu yüzden bu gece

Yakacă̆gz ve talan edeceğiz

Bob Marley, Burnin' and Lootin' şarkı sözleri(filmin giriş müziği), 1973

Yakın zamana kadar, Avrupa getto terimini pek kullanmiyorken, ne oldu da politik, medya hatta akademik alanda kullanımı sıklaştı? Wacquant'ın Avrupa'daki işçi sınıf yaşam alanlarını ve Amerikan gettolarının yapısal ve işlevsel farklılıklarını ortaya koymasına rağmen, getto-gettolaşma kavramlarının kullanımının karşısında durmasının altında "Yahudi gettoları ile özdeş algısından ötürü" gibi naif bir bağlantı görmek isteyenler olabilir. Avrupa işçi sınıfı yaşam alanı ve banliyölerini, getto ve hiper-gettodan farklı olduğunun altını çizen Wacquant'ın bu sosyo-mekânsal alanları anti-getto olarak adlandırılmasının temel nedenleri; yapısal, işlevsel, demografik özelliklerinin farklı olmasından ileri gelmektedir. Diğer yandan; 1996 y1lında Almanya'daki Türk ve Müslüman azınlıkların kendi içine kapalı yaşamlarını ifade eden "paralel yaşamlar" kelimesi de yaygın olarak kullanılmakta olmasiyla birlikte, siyaset ve medya söylemlerinde bu kavramların aynılaştırılmaya çalışılmasının altında sembolik şiddetin uygulandığı anlamını çıkarmaktayım. İster getto, isterse banliyö olsun, ister gönüllü ister zorunlu olsun tüm sosyo-mekânsal inzivaların arkasında damgalama olduğu bir gerçektir. Bunun yanında ötekileştirme ile birlikte medya ve politikada 
kullanılan dillerin giderek sertleşmesi, hukuki anlamda bu bölgelerde yaşayanlara yaptırımların arttırılması ile mekânsal eşitsizliklerin altı kalın kalemlerle çizilerek kentte yoğunlaşmaya başladığı gözlemlenmektedir.

Son yıllarda dünya üzerinde sivil eylem ve direnişlerin mekânı olan kentlerde ortaya çıkan bu hareketler farklı içeriklere sahip olsalar da temelde eşit kent hakkı istekleri noktasında birleşirler. Bu hareketlerin bir üçüncü alan yaratma potansiyeli olabilir. Ancak ortaya çıkan sosyal ve fiziksel anlamda oransız güç kullanımı ve hukukun askıya alınması durumu, insan hakları bakımından kabul edilebilir değildir. Cezanın suçu önlediği, şiddetin şiddeti doğurmadığı örnekler açısından tarihsel süreç elimizi zenginleştirmemektedir. Sembolik şiddetin toplum üzerindeki psikolojik etkisi, fiziksel şiddetin oluşturduğu etkiden daha az olmayacaktır.

Kentsel eşitsizlik temelinde birbiri ile sıkı sıkıya ilişkili sosyal, kültürel, ekonomik ve mekânsal bagajlarının sistemin içinde olmak istemeyen aslında sistem dışına atılmış toplulukların gerilimlerini tetiklediği anlaşılmaktadır. Avrupa banliyöleri özelinde devletin militer yüzünün yoğunluğu ile karşılarız. Medya ve politik söylemde mekânsal damgalamanın ivmelenerek arttı̆̆ı, neoliberal ekonomik yapılanmalarla iş hayatının dışına itildiği çoğunlukla göçmenlerin oluşturduğu nüfusun sosyo-mekânsal olarak kentte 'gettolaştığı iddia edilen' sürgün yerlerine sıkıştırıldığ1 tabloda, 'yere düşüş anı'nın nasıl olacağına dair korku senaryoları üretilir. Oysa 'patronla konuşmak için daha ne kadar nehir geçilecektir?' ki... 


\title{
Extended Abstract
}

\section{Socio-spatial Seclusion in the Context of the "Ghettozation" Discourse}

\begin{abstract}
Abandonment of welfare state politics in the results of the 1973 economic crisis of capitalism and in relation to that increases of ethnical, racial, classbased unrests brought out the acceleration of urban resistances. The resistances are generated as a scream of being dispossession, disemployment and incurring to structural violence with the neoliberal politics essentially derive economic and spatial inequalities. As well as the marginalized urban outcast with urban space which is seen as dangerous and urban resistance, the concerns about reinvigoration of racism in European society arose. Besides that, we witness how the state's interventions on urban movements are heavily militant and discussions on the penalization system.

Although the roughly twenty years are passing out of Wacquant's structural analysis of the ghetto / anti-ghetto / hyper-ghetto concepts, the insistence of the use of the ghetto concept by politicians suggests that it is manipulative. According to the Wacquant who traces the historical transition from the communal ghetto in the mid-20th century to hyper-ghetto in the end of the 21st century, all social classes of blacks are tied to a place reserved for themselves in communal ghettos in US cities; in these limited areas, a common fate is experienced in a cramped socio-spatial formation in the presence of the institutions specific to this ethnic group; hyper-ghetto is a new, decentralized, organized structure that is limited to a certain region. There is a unified distinction on the basis of race and class. The marginalization of the communal ghetto of the 50's and the transformation of the habitats that becoming insecure into the 90's hyper-ghetto was also adversely affected the habitant's sense of belonging. Wacquant stands against to discourse of ghettoization of suburb which is generated from superficial similarity of advanced marginalized occurrences, because of the structural and functional differentiation of both like banlieue's heterogenic structure, its relation with the city center and the state's politics. He asserts that the working class settlements can not be ghettoes, but can be anti-ghetto. On the other hand,
\end{abstract}


naming with concepts of ghetto-ghettoism ignoring the etymological differences of the concepts in the European working class settlements (cité), the curse of parallel lives, the emergence of similar discourses that systematize such discourses in Europe is a situation that should not be overlooked considering the global conjectural politics and economy. Communities that are unemployed, segregated by ethnic-class basis are stigmatized in a spatial manner by media and politics.

In this context, the framework of the study reveals the structural and functional differences of the European working class habitats and ghettos as different forms of socio-spatial seclusion in the relation with symbolic power and symbolic violence concepts. Basically, this study is based on the description of Wacquant's 'Designing Urban Seclusion' seminar describing the history of urban seclusion which was given in Yale University in the USA in 2014, and the book of 'Urban Outcasts' where advanced marginality is discussed through American and European examples. In this study, which is read Wacquant approaches via La Haine film; La Haine film is preferred because the daily life in the suburbs is strongly emphasized as a very different from stereotyped stereotypes in the film and the film music that represents the suburban music culture. During the writing process, the emergence of "yellow vest protests in different European cities" and those subsequent rise in the media reflect to the methodology of paper in the context of critics of European suburbs and violence relation discourses. Within the framework of Foucault's discursive practices and Bourdieu's symbolic violence concepts, a critical approach to media discourse is developed.

We witness that today's Europe is increasingly transformed into a criminal state in the politics of coping with advanced marginality as the emerging form of urban outcasts. In the suburb of La Haine, a suspended democracy appears to exist. The situation of the inhabitants who do not even think about looking for legal means against police violence in the film shows how the state of exception is normalized in everyday life. In recent years, the protests in the cities, which are the places of civil action and resistance on the world, even they have different contents, but they basically unite in the same way that they have equal rights of the city. These movements may have the potential to create a third space. However, the occurrence of social and physical disproportionate use of force and the suspension of law are not acceptable for human rights. 
Whether ghetto or suburban, voluntary or involuntary, it is a fact that there is spatial stigmatization at the background of any socio-spatial seclusion. In addition to this, it is observed that the spatial inequalities are concentrated in the city by the languages used in the media and politics are getting harder and the legal implications are increased. It is understood that social, cultural, economic and spatial baggage, which are closely related to each other on the basis of urban inequality, trigger the tensions of the societies that have been pushed out of the system. In the case of European suburbs, we see the intensity of the military face of the state. The nature of exile locations can be understood by the questioning of the political, economic and social history and relationships.

\section{Kaynakça/ References}

Agamben, G. (2013). Kutsal insan: Egemen iktidar ve çplak hayat. (İsmail Türkmen, çev.). İstanbul: Ayrıntı Yayınları. (orjinal eserin yayın tarihi 1995).

Bourdieu, P. ve Wacquant, L. (2003). Düşünümsel bir antropoloji için cevaplar. (N. Ökten, çev.). İstanbul: İletişim Yayınları (orjinal eserin yayın tarihi 2001).

Bourdieu, P. 1991. Language and symbolic power. John B. Thompson (Der.). Politiy Press, US.

Castaneda, E. (2012). Places of stigma: Ghetto, barrios and banlieues. (R. Hutchison ve B. D. Haynes, Der.). The Ghetto: Contemporary Global Issues and Controversies in (pp. 159-190). US: Westview Press,.

Foucault, M. (2006). Deliliğin tarihi. (M.A. Kılıçbay, çev.). Ankara: İmge Yayınevi (orjinal eserin yayın tarihi 1961).

Hall, S. (2017). Temsil: Kültürel temsiller ve anlamlandırma uygulamaları. (İ. Dündar, çev.). İstanbul: Pinhan Yayıncllk (orjinal eserin yayın tarihi 1997).

Lazzarato, M. (2015). Göstergeler ve makineler. (F. N. Demirci, çev.). İstanbul: Otonom Politika Yayıncilık (orjinal eserin yayın tarihi 2015).

Merrified, A., Negri, A., Bayat, A., Harvey, D., Wacquant, L., Amoros, M., Torlak, S., (2014). Mekân meselesi. (S. Torlak, Ö. Kulak Der.). İstanbul: Tekin Yayınevi.

Sarı, A., (17.2.2011). Etienne Balibar: Demokrasinin tarihsel ikilemleri ve çağdaş yurttaşlık. Rethinking Marxism (2008) Cilt 20, Sayı 4, (s. 522-538) çev), 16 Aralık 2018 tarihinde, https://onbirincitez.wordpress.com/2011/02/17/etiennebalibar-demokrasinin-tarihsel-ikilemleri-ve-cagdas-yurttaslik/ adresinden erişildi.

Standing, G. (2014). Prekarya, yeni tehlikeli sınıf. (E. Bulut, çev.). İstanbul: İletişim Yayınları (orjinal eserin yayın tarihi 2011).

Swartz, D. (2011). Kültür ve iktidar: Pierre Bourdieu'nün sosyolojisi. (E. Gen, çev.). İstanbul: İletişim Yayınları (orjinal eserin yayın tarihi 1997). 
Wacquant, L. (2013). Simgesel iktidar ve grup oluşumu: Pierre Bourdieu'nün sınıfı yeniden çerçevelemesi üzerine. Cogito, Sayı: 76, s.204-230.

Wacquant, L., (2014). Designing urban seclusion. (Yale Üniversitesi Semineri). 10 Aralık 2018 tarihinde, https://www.youtube.com/watch?v=UsqWyLoK2wE adresinden erişildi.

Wacquant, L., (2015). Kent paryaları: İleri marjinalliğin karşılaştırmalı sosyolojisi. (M. Doğan, çev.). İstanbul: Boğaziçi Üniversitesi Yayınevi (orjinal eserin yayın tarihi 2008).

Asiye Akgün Gültekin, 1999 yılında Yıldız Teknik Üniversite Mimarlık Fakültesi Mimarlık Lisansının ardından, 2002 yılında İstanbul Teknik Üniversitesi Mimari Tasarım Ana Bilim Dalı'nda Yüksek Lisans ve 2012 yılında Doktorasını tamamlamıştır. İstanbul Kültür Üniversitesi Mimarlık Fakültesi'nde 2007 yılından itibaren akademisyen olarak çalışmaktadır. Başlıca çalışma alanları; mekanın ekonomi politiği, mekânsal dışlama ve ayrışmadır.

Asiye Akgün Gültekin, Received her B.Arch in Architecture from Yildiz Technical University Faculty of Architecture (1993-1999). Received her MSc. (2000-2002) and earned her PhD. degree (2002-2012) in Architectural Design Programme from Istanbul Technical University. Currently works as an Assistant Professor at Istanbul Kültür University. Major research interests include economic policy of space, spatial exclusion and segregation.

E-mail: a.akgun@iku.edu.tr 